\title{
DIMENSIONS OF CSR IN ONLINE COMMUNICATION OF PHARMACEUTICAL COMPANIES: A COMPARATIVE STUDY
}

\author{
Milan Džupina \\ Constantine the Philosopher University in Nitra \\ Nitra, Slovak Republic \\ mdzupina@ukf.sk
}

\section{Zuzana Džupinová}

Institute for State Control of Veterinary Biologicals and Medicaments

Nitra, Slovak Republic

zdzupinova@gmail.com

\begin{abstract}
The article focuses on analysis of online communication of pharmaceutical companies in the field of CSR. It is based on the fact that there are specific segments in the economy, which are called sensitive sectors. Even though they are often perceived as irresponsible in their nature, there are effective communication tools, which can used to increase positive corporate image. The present study is a part of a larger research that we conducted in the segment of pharmaceutical industry. We used information about companies available on their websites as a research material. We reviewed their availability on websites, but we also reviewed the content on which companies usually focus in terms of social engagement. Our research was supposed to prove that there are considerable differences among companies in our sample. We analyzed (qualitative content analysis) collected data (basic corporate documents like mission, vision and corporate values) using statistical procedures. These documents are crucial to corporate strategies, and often deal with responsibility issues which are then transformed into business strategies, tactics and programs. According to the nature of the research the generalization of the information provided is relatively limited.
\end{abstract}

KEYWORDS: corporate social responsibility (CSR), pharmaceutical industry, sensitive sector, content analysis.

JEL CLASSIFICATION: M14, M31, Q13.

Received: October $17^{\text {th }}, 2019$

1st Revision: November $29^{\text {th }}, 2019$

Accepted: December 2 $2^{\text {nd }}, 2019$

DOI: $10.2478 / \mathrm{IJEK}-2019-0009$

Džupina, M., Džupinova, Z. (2019). Dimensions of CSRE in Online Communication of Pharmaceutical Companies: A Comparative Study. International Journal of Entrepreneurial Knowledge, 6(2), 41-52. doi:10.12345-0009

\section{INTRODUCTION}

Pharmaceutical industry is often considered both very admired and criticized, too (Nussbaum, 2009) and is one of today's most dynamic industries worth US $\$ 300$ billion a year. Moreover, a figure is expected to rise up to US $\$ 400$ billion within three years (World Health Organization, 2016). Pharmaceutical industry has many peculiarities due to its specific character. I has a top sophisticated research, fierce competition and regulations. Although the concept of corporate social responsibility (CSR) can be traced back to 50s pharmaceutical sector began to adopt CSR only about a short time ago. Finally, PR managers soon understood, that it is very important to report on sustainability and responsibility and the number of firms is still increasing (Esteban, 2008). Pharmaceutical industry is often stigmatized due to the character of the production, but CSR seems to be an appropriate tool to secure broader stakeholder support (Hillenbrand, Money, \& Ghobadian, 2013). Even though, these firms produce drugs and medicines to improve and maintain human and animal well-being, they are often perceived as “sin” (Grougiou, Dedoulis, \& Leventis, 2016), or sensitive industry (Kašparová \& 
Kunz, 2013), or even stigmatized sector (Vegne, 2012). It is mainly because of their nature and conflict between words and actions. Recent researches focus mainly on the pharmaceutical industry ethics and sincerity nexus (Countess of Frederiksborg \& Fort, 2014; Nussbaum, 2009); a customer perception and analysis of attitudes towards CSR activities of pharmaceutical firms (Wang, 2011); CSR as a means of public relation and reputation management (Cheah, Chan, \& Chieng, 2007; Stone, Grantham, \& Vieira, 2009; Leisinger, 2005); but also advantages of implementing CSR in the pharmaceutical sector (Droppert \& Bennett, 2015). Active CSR can lead to stronger corporate brands, employee satisfaction, positive corporate image or teambuilding (Nielsen \& Thomsen, 2007; Story \& Price, 2006).

\section{DEFINITION OF CORPORATE SOCIAL RESPONSIBILITY (CSR)}

The problem with CSR is that there is an ambiguity of what CSR entails (Džupina \& Džupinová, 2016). There is no generally accepted definition of CSR as they usually apply in specific time, country of origin, or to a specific stakeholder group. At least 37 main academic definitions can still be identified emphasizing the responsibility categories and issues (Dahlsrud, 2008). The modern era of CSR is marked by the contribution of H. R. Bowen (Carroll, 1999), who concluded that businessman were obliged to "pursue those policies, to make those decisions, or to follow those lines of action which are desirable in terms of the objectives and values of our society..." (Bowen, 1953: 6). Later on, Carroll (1979) defined CSR as "The social responsibility of business encompasses the economic, legal, ethical, and discretionary expectations that society has of organizations at a given point in time." and formulated a four-stage model of corporate social responsibility (Carroll, 1979). Definitions also dealt with the notion of voluntarism and it was believed, that companies should fulfill and enhance socioeconomic welfare in 1960s (Frederick, 1960). An important shift occurred in 1970's when Sethi (1975) started distinguishing among corporate behavior (social obligation), social responsibility, and social responsiveness. During 1990s, new definitions started to deal with internal and external stakeholder and also a new concept of "Triple Bottom Line" was placed (Elkington, 1999). There was also a very complex definition formulated by Vogel (2005), who claimed, that CSR represented "practices that improve the workplace and benefit society in ways that go above and beyond what companies are legally required to do". Nowadays, according to the European Union, CSR is "a concept whereby companies integrate social and environmental concerns in their business operations and in their interaction with their stakeholders on a voluntary basis" (European Commission, 2001).

\section{CSR IN PHARMACEUTICAL COMPANIES}

There were several researches conducted in pharmaceutical companies, which prove that one of the basic principles of their philosophy is to take care of the interests and needs of the final consumer those who buy pharmaceutical products but also the whole society (Vitezić, 2010). Firms in all sectors, including pharmaceutical industry, are implementing programs and strategies to improve social welfare, protect the environment and, finally to protect human rights (the social pillar). There is a global increase in the importance and subsequently impact of social responsibility in the pharmaceutical industry (Porter \& Kramer, 2002). However, dimensions of economic sustainability also play an important role in overall sustainability as they are vital for further economic sustainability and development in the future (Džupina \& Džupinová, 2016). Vitezić (2010) identified a new revised CSR model of pharmaceutical companies (figure 1) which differed from the original version of the sustainability model as it emphasized the human factor (human driving forces) in the pharmaceutical industry. The human pillar consists of such dimensions like improving the quality of life, improving the health culture, prevention and treating of diseases (Vitezić, 2010). CSR in the pharmaceutical industry is not only about altruism but also about comfort (Fort, 2014). According to Bowen (2004, p. 321), a pharmaceutical company wish to be perceived as socially responsible because it is very important for their reputation (Bowen, 2004: 321). Even though pharmaceutical companies are perceived as irresponsible, in fact they can be more responsible than other companies (Minoja, Romano, 2010) 
mainly because they play a key role in improving public health, of course while meeting desired profitability (Reisel, Sama, 2003). It is necessary to find a compromise in meeting all stakeholders' expectations.

Figure 1 A Model of A Socially Responsible Pharmaceutical Company

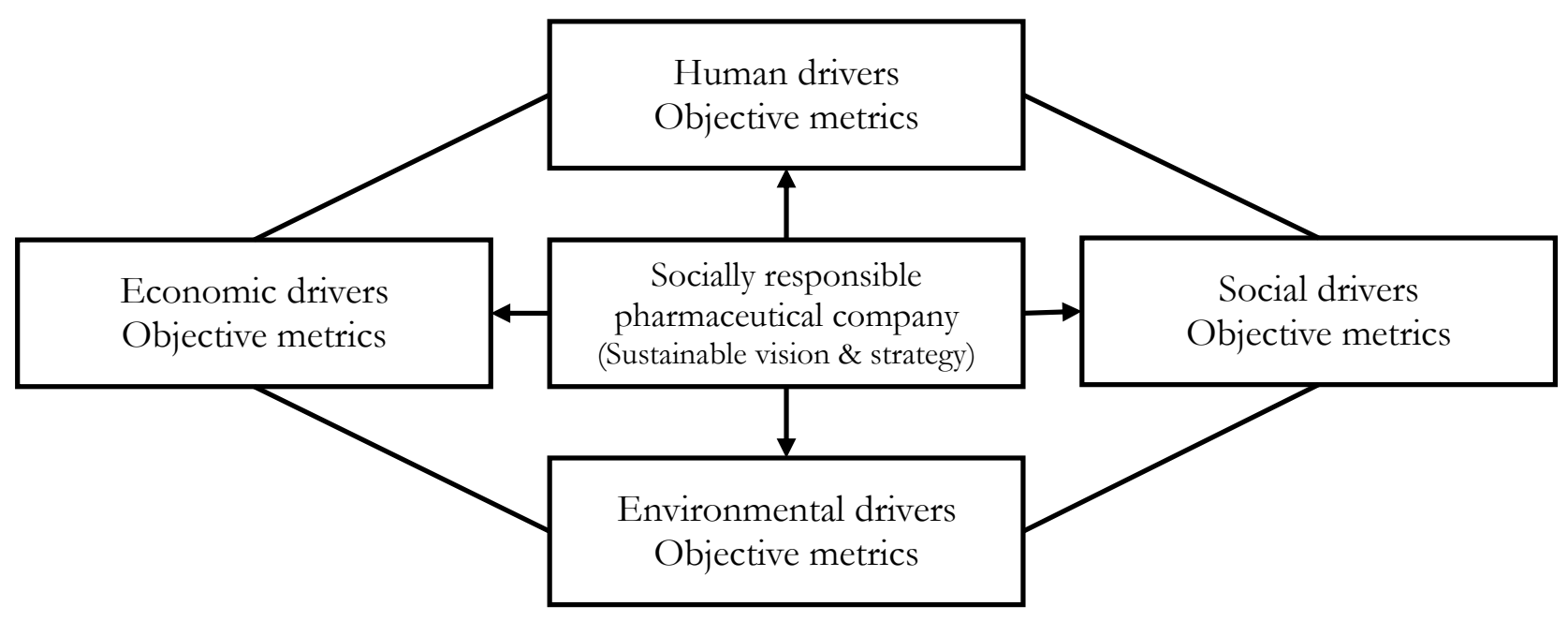

(Source: Vitezić, N., 2010: 64)

Aspect of profitability is vitally important for pharmaceutical companies. Otherwise, they would lack financial sources for further research, product development, innovation skills or reduction of investments (Smith, 2003). With regard to CSR, there are several different approaches for pharmaceutical companies how to deal with sustainability issues. We believe that corporate executives should focus on activities, which include more management efforts and skills as well as their know-how in implementing CSR (Esteban, 2008). In last few years, we have noticed, that importance of CSR is increasing within pharmaceutical industry (Leisinger, 2005). Mainly due to a negative publicity, which was triggered by low quality of production and subsequent withdrawal of medicines from the market (Cheah, at al., 2007). Other issues were caused by problems with clinical testing, safety of medical products, advertising and overuse of drugs, corruption, work safety, or even biopiracy (Weyzig, 2004). Usually, managers implement codes of conduct to avoid such a behavior (Seknička \& Putnová, 2016). Implementation of appropriate CSR policies can positively influence brand equity (Hoeffler \& Keller, 2002), employee satisfaction, goodwill, teambuilding or social development (Nielsen \& Thomsen, 2007; Story \& Price, 2006). Nowadays, the situation with pharmaceutical companies have changed. Marketing 4.0 helped to introduce new platforms, which can be relatively cheaply used to communicate with stakeholder groups. The main advantages are proactivity and adaptability of the message spread through new channels (Manheim \& Pratt, 1986; Tapscott \& Tiscoll, 2003; Xiao, et al., 2002).

\subsection{Online CSR}

Nowadays, we witness the move of marketing communication to digital environment, namely online environment. The number of people with access to new technologies and internet connection is growing rapidly (Esrock \& Leichty, 1998). Digital forms of communication changed the way in which brands communicate interact with customers (Benmark \& Masri, 2015). The most commonly mentioned advantages of online communication are (1) interactivity (De Pelsmacker, et al., 2010), efficiency (Chaffey \& Ellis-Chadwick, 2016) and reliability (Homburg, et al., 2009). Studies on online CSR communication have been conducted for over two decades. Esrock and Leichty (1998) analyzed the impact of online CSR on business image. They concluded that online communication helped to present companies, monitor the interests of stakeholders and that it would lead to a direct dialogue between companies and their audience. Therefore, CSR can be seen as a means of active image management. Companies have the opportunity to differentiate their own brand at a relatively low cost 
and communicate about their corporate social responsibility and build credibility through new channels in their communication mix (Kesavan, et al., 2013). Digital environment includes wide range of different channels, through which companies can stay in touch with its important stakeholders (Arrenfeldt, 2015). Thus, increasing the potential number of brand contacts. Today, the Internet is used by public relations professionals to provide information to online public (such as shareholders, customers, suppliers, employees, media, etc.). Gomez and Chalmeta (2011) discussed the main features of CSR on websites, which are presentation features, content features and interactive features. More than half of the companies present their social responsibility through environmental projects, education projects and social engagement (Esrock \& Leichty, 1998). Surprisingly, many pharmaceutical companies still do not make an adequate use of the Internet to communicate about CSR (Uzunoglu \& Kip, 2014). Ryan (2003) identified two ways in which organizations communicate with interest groups. Firstly, a one-way communication, which is aimed at spreading basic in order to influence the final image. Secondly, a dialogue-based communication, which is vital for the concept of integrated marketing communication

Leichty and Esrock (1998) in their article referred to the findings of Weber (1990), which emphasized the need to tailor reports to individual interest groups (journalists, analysts, opinion leaders and others). Subsequently, they recommended to specify the type and extent of information based on their content, for example financial data, social responsibility, job opportunities or any other aspects that need to be communicated through business communication. New technologies have made tremendous progress in the field of CSR communication. There are many opportunities to communicate social responsibility and target the information depending on the interests of stakeholder groups. In addition, innovative technologies offer opportunities to improve the quality of stakeholder relationships and also more accurate measuring of the communication goals.

\section{DATA AND METHODS}

The sample was obtained from the list of all pharmaceutical drugs producers registered in the Slovak Republic. Most of them are branches of large multinational corporations, so they are very likely to have web sites developed. For the purpose of the study, we will analyze all 70 companies to cover the whole sector. The research procedure consisted of several steps. First step is based on our previous research, in which, we have gathered a few definitions of CSR through a literature review from 1950s to a socalled millennium era (Džupina, 2012). Subsequently, we identified basic pillars and dimensions of CSR in gathered definitions (as shown in table 1).

Table 1 Pillars and dimensions of corporate social responsibility

\begin{tabular}{|c|c|c|c|}
\hline \multicolumn{4}{|c|}{$\begin{array}{l}\text { Stakeholders } \\
\text { Voluntarism }-\bar{y}^{-}-{ }_{\text {I }}\end{array}$} \\
\hline \multicolumn{4}{|c|}{ Obligations to society } \\
\hline \multirow{2}{*}{ 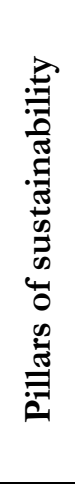 } & $\begin{array}{l}\text { Financial } \\
\text { responsibility }\end{array}$ & $\begin{array}{l}\text { - } \text { corporate governance, } \\
\text { - } \text { profitability, } \\
\text { - product quality and safety, } \\
\text { - ethical behavior, } \\
\text { - CRM, } \\
\text { - fight against corruption, }\end{array}$ & $\begin{array}{l}\text { - transparency, } \\
\text { - protection of intellectual property, } \\
\text { - fair trade, } \\
\text { - fair competition, } \\
\text { - business and marketing ethics, }\end{array}$ \\
\hline & $\begin{array}{l}\text { Social } \\
\text { responsibility }\end{array}$ & $\begin{array}{l}\text { - health and safety at work, } \\
\text { - employment policy, } \\
\text { - education of employees, } \\
\text { - employing the long term unemployed, }\end{array}$ & $\begin{array}{l}\text { - respecting human rights, } \\
\text { - work-life balance } \\
\text { - outplacement } \\
\text { - humanizing workplace, }\end{array}$ \\
\hline
\end{tabular}




\begin{tabular}{|c|c|c|}
\hline & $\begin{array}{l}\text { - sponsoring and philanthropy, } \\
\text { - corporate volunteering, } \\
\text { - anti-discrimination policy, } \\
\text { - fight against child labor, }\end{array}$ & $\begin{array}{l}\text { - employee-friendly work environment, } \\
\text { - equal working conditions, } \\
\text { - partnership with stakeholders }\end{array}$ \\
\hline $\begin{array}{l}\text { Environmental } \\
\text { responsibility }\end{array}$ & \multicolumn{2}{|c|}{$\begin{array}{l}\text { - "green" corporate policy and culture } \\
\text { - reduction of negative impacts on the environment, } \\
\text { - "green" production and "green" products (ISO 14000, EMAS, etc.). } \\
\text { - saving and protection of natural resources, } \\
\text { - "green" investments, and investments to "green" technologies, }\end{array}$} \\
\hline
\end{tabular}

(Source: Džupina, 2012: 65)

Thirdly, we gathered information from online communication focusing on CSR on corporate web sites and in strategic documents. Companies were obtained from the list of pharmaceutical drugs producers registered in the Slovak Republic. A content analysis with an open coding scheme was used to identify all dimensions in corporate missions and visions, possibly corporate values. All the companies were picked up on purpose and all the subcontractors were excluded from the list. We used IBM SPPS 25.0 for statistical evaluation. We have found that our research sample is made up mainly of multinational companies $(77.1 \%$ ) and only $22.86 \%$ are of Slovak origin. Our sample consisted not only of those companies that produce human drugs, but also veterinary drugs. $11.4 \%$ of companies produce only human drugs, $47.1 \%$ focus on veterinary drugs and $41.4 \%$ produce both. We decided to include all producers registered by the Slovak authorities and included in the database on www.eudragmp.ema.europa.eu website. The main objective of the paper was to determine the main differences between Slovak and foreign companies in our sample. Partially, we tried to answer following research questions:

1. Is there a statistically significant impact of country of origin on CSR activities?

2. Is there a difference between pillars of sustainability between Slovak and foreign companies?

3. Is there a statistically significant difference between Slovak and foreign companies in terms of preferring CSR dimensions?

\section{RESULTS AND DISCUSSION}

In our research, we focused on issue of differences in the social engagement of Slovak and foreign pharmaceutical companies. It is based on the total number of dimensions in which the companies were involved. The research sample consisted of only those companies, which reported their CSR on web pages. It was $54(77.1 \%)$ out of the 70 enterprises analyzed. The average number of CSR activities in which companies were involved 10.8 .

\section{Table 2 Geographical differences CSR engagement according to the country of origin}

\begin{tabular}{||l|r|r||}
\hline \hline STATISTICS & \multicolumn{1}{|c|}{ SLOVAK COMPANIES } & \multicolumn{1}{|c|}{ FOREIGN COMPANIES } \\
\hline $\mathrm{N}$ & 10 & 44 \\
\hline Mean & 5,50 & 11,95 \\
\hline Std. Error of Mean & 1,09 & 1,17 \\
\hline sStd. Deviation & 3,44 & 7,73 \\
\hline Variance & 11,83 & 59,77 \\
\hline Median & 4,00 & 12,00 \\
\hline Skewness & 1,23 &, 21 \\
\hline Std. Error of Skewness &, 69 &, 36 \\
\hline Kurtosis & 1,15 & $-1,15$ \\
\hline Std. Error of Kurtosis & 1,33 &, 70 \\
\hline
\end{tabular}




\begin{tabular}{|l|r|r|}
\hline Range & 11 & 26 \\
\hline Minimum & 2 & 1 \\
\hline Maximum & 13 & 27 \\
\hline
\end{tabular}

(Source: Own research processed in IBM SPSS 25.0)

The table shows that the average difference between Slovak $(\varnothing=5.5)$ and foreign $(\varnothing=11.6)$ entities is significant in terms of involvement in CSR activities. In order to carry out statistical testing, it is necessary to determine separately if the distribution of the variable is normal in both Slovak and foreign companies. The normality of distribution is necessary for the performance of parametric statistical testing.

Table 3 Test of normality (Kolmogoro-Smirnov a Shapiro-Wilkoksov test)

\begin{tabular}{||l|r|r|r|r|r|r||}
\hline & \multicolumn{2}{|c|}{ KOLMOGOROV-SMIRNOV } & \multicolumn{3}{c||}{ SHAPIRO-WILK } \\
\cline { 2 - 7 } & Statistic & \multicolumn{1}{|c|}{$\mathrm{df}$} & \multicolumn{1}{c|}{ Sig. } & \multicolumn{1}{c|}{ Statistic } & \multicolumn{1}{c|}{ df } & \multicolumn{1}{c|}{ Sig. } \\
\hline Slovak companies &, 269 & 10 &, 039 &, 851 & 10 &, 059 \\
\hline Foreign companies &, 144 & 44 &, 023 &, 934 & 44 &, 015 \\
\hline
\end{tabular}

(Source: Own research processed in IBM SPSS 25.0)

In the case of Slovak companies, the deviation from the normal distribution is not statistically significant $(\mathrm{p}>$.005) based on the Shapiro-Wilk test, which has a higher power to detect deviations from the normal distribution (Field, 2009). However, for foreign business companies, the situation is the opposite. The $\mathrm{p}$ value $(\mathrm{p}<.005)$ indicates that the distribution of CSR dimensions of foreign firms compared to the normal distribution is statistically significant. Thus, we decided to proceed with nonparametric testing to see if the impact of the country of origin is statistically significant.

Table 4 Impact of country of origin on a number of CSR dimensions

\begin{tabular}{|l|r|r|r||}
\hline & $\mathrm{N}$ & MEAN RANK & SUM OF RANKS \\
\hline Slovak companies & 16 & 23,78 & 380,50 \\
\hline Foreign companies & 54 & 38,97 & 2104,50 \\
\hline Total & 70 & & \\
\hline \hline
\end{tabular}

(Source: Own research processed in IBM SPSS 25.0)

According to the calculations which were carried, we found that there was a realistic assumption that differences in different levels of enterprise engagement could be caused by the country of origin. Nonparametric statistical tests are based on medians of distributions and therefore have a higher informative value compared to the classical arithmetic mean.

\section{Table 5 Impact of country of origin on a number of CSR dimensions (Mann-Whitney test)}

\begin{tabular}{||l|r|}
\hline \hline Mann-Whitney U & 244,500 \\
\hline Wilcoxon W & 380,500 \\
\hline Z & $-2,642$ \\
\hline Asymp. Sig. (2-tailed) &, 008 \\
\hline
\end{tabular}

(Source: Own research processed in IBM SPSS 25.0);

a. Grouping Variable: Slovak/foreign company 
The total number of dimensions that foreign enterprises have included in their CSR policies $(\mathrm{Mdn}=12)$ is statistically significantly different from the Slovak $(\mathrm{Mdn}=4), \mathrm{U}=244.50, \mathrm{z}=-2.64$, $\mathrm{p}<.01$. We are aware that non-parametric tests are less sensitive than parametric tests. In order to increase the informative value, we have determined the effect of the country of origin, which is based on the formula (1):

$$
r=\frac{Z}{\sqrt{N}}
$$

Where Z - Z statistics,

$\mathrm{N}$ - Number of cases

Based on the defined relationship, we calculated $r=-0.36$, which implies that the relationship between the country of origin and the CSR activities is explained to about $36 \%$. This is a weak relationship in which there are still $64 \%$ chance of other factors influencing the statistical model. Moreover, we also observed differences in the specific pillars that Slovak and foreign companies prefer in their CSR strategies.

\section{Table 6 Pillars of sustainability}

\begin{tabular}{||c|c|c|c|c||}
\hline \multirow{2}{*}{ PILLARS } & \multicolumn{2}{|c|}{ SLOVAK COMPANIES } & \multicolumn{2}{c||}{ FOREIGN COMPANIES } \\
\cline { 2 - 5 } & $\mathrm{N}$ & $\%$ & $\mathrm{~N}$ & $\%$ \\
\hline Economic & 10 & $100,0 \%$ & 42 & $95,5 \%$ \\
\hline Social & 8 & $80,0 \%$ & 35 & $64,8 \%$ \\
\hline Environmental & 6 & $60,0 \%$ & 32 & $59,3 \%$ \\
\hline
\end{tabular}

(Source: Own research processed in IBM SPSS 25.0)

As far as sustainability is concerned, the situation is in both Slovak and foreign companies relatively similar. In both groups of companies, the economic pillar of sustainability dominates. The percentages do not have significant information value, as Slovak companies are not sufficiently represented in the sample. However, it simply illustrates what pharmaceutical market looks now. It is highly dominated by foreign corporations. Another problem is that Slovak companies pay less attention to reporting CSR activities.

Another question, which we tried to answer was whether there are statistically significant differences in dimensions, which both Slovak and foreign companies prefer. However, the results could be influenced by a smaller number of Slovak companies (table 7 and table 8 ).

\section{Table 7 Dimensions of CSR in Slovak companies}

\begin{tabular}{|c|c|c|c|}
\hline DIMENSIONS & PILLARS & $\mathrm{N}$ & $\%$ \\
\hline Product safety and quality (animal health) & Econ. & 8 & $80,0 \%$ \\
\hline Occupational safety and health & Soc. & 6 & $60,0 \%$ \\
\hline Employee education & Soc. & 5 & $50,0 \%$ \\
\hline Consumer relationships & Econ. & 5 & $50,0 \%$ \\
\hline Ecological production (ISO 14000, 50 000, EMAS, HSEQ) & Ecol. & 4 & $40,0 \%$ \\
\hline Green investments & Ecol. & 4 & $40,0 \%$ \\
\hline Green corporate culture & Ecol. & 3 & $30,0 \%$ \\
\hline Reduction of negative environmental impacts & Ecol. & 3 & $30,0 \%$ \\
\hline Stakeholder partnership & Soc. & 3 & $30,0 \%$ \\
\hline Code of conduct & Econ. & 3 & $30,0 \%$ \\
\hline Natural resources protection & Ecol. & 1 & $10,0 \%$ \\
\hline
\end{tabular}




\begin{tabular}{||l|r|r|r||}
\hline \hline Waste management & Ecol. & 1 & $10,0 \%$ \\
\hline Low cost environment & Ecol. & 1 & $10,0 \%$ \\
\hline Philanthropy & Soc. & 1 & $10,0 \%$ \\
\hline Anti-discrimination policy & Soc. & 1 & $10,0 \%$ \\
\hline Diversity management & Soc. & 1 & $10,0 \%$ \\
\hline Human rights & Soc. & 1 & $10,0 \%$ \\
\hline Fight against corruption & Soc. & 1 & $10,0 \%$ \\
\hline Transparency & Econ. & 1 & $10,0 \%$ \\
\hline Fair competition & Econ. & 1 & $10,0 \%$ \\
\hline Reduction of water, waste and electricity consumption & Econ. & 1 & $10,0 \%$ \\
\hline COO 2 & Ecol. & 0 & $0,0 \%$ \\
\hline Work-life balance & Ecol. & 0 & $0,0 \%$ \\
\hline Friendly corporate culture & Soc. & 0 & $0,0 \%$ \\
\hline Corporate governance & Soc. & 0 & $0,0 \%$ \\
\hline Protection of intellectual property & Econ. & 0 & $0,0 \%$ \\
\hline Marketing ethics & Econ. & 0 & $0,0 \%$ \\
\hline \hline
\end{tabular}

(Source: Own research processed in IBM SPSS 25.0)

The interesting thing is that in Slovak companies, there are mainly dimensions of ecological sustainability in the first half of the table compared to foreign entities. In the first half of the dimensions, there are up to $50 \%$ of the dimensions related to the environmental orientation of companies, $28.60 \%$ of social dimension and only $21.40 \%$ dimensions of economical sustainability.

\section{Table 8 Dimensions of CSR in foreign companies}

\begin{tabular}{|c|c|c|c|}
\hline DIMENSIONS & PILLARS & $\mathrm{N}$ & $\%$ \\
\hline Product safety and quality (animal health) & Econ. & 39 & $88,6 \%$ \\
\hline Consumer relationships & Econ. & 33 & $75,0 \%$ \\
\hline Code of conduct & Econ. & 29 & $65,9 \%$ \\
\hline Stakeholder partnership & Soc. & 28 & $63,6 \%$ \\
\hline Employee education & Soc. & 27 & $61,4 \%$ \\
\hline Occupational safety and health & Soc. & 24 & $54,5 \%$ \\
\hline Philanthropy & Soc. & 23 & $52,3 \%$ \\
\hline Ecological corporate culture & Ecol. & 22 & $50,0 \%$ \\
\hline Reduction of negative environmental impacts & Ecol. & 22 & $50,0 \%$ \\
\hline Reduction of water, waste and electricity consumption & Ecol. & 22 & $50,0 \%$ \\
\hline Employment policy & Soc. & 22 & $50,0 \%$ \\
\hline Natural resources protection & Ecol. & 20 & $45,5 \%$ \\
\hline Transparency & Econ. & 20 & $45,5 \%$ \\
\hline Ecological production (ISO 14000, 50 000, EMAS, HSEQ) & Ecol. & 19 & $43,2 \%$ \\
\hline Waste management & Ecol. & 19 & $43,2 \%$ \\
\hline Anti-discrimination policy & Soc. & 19 & $43,2 \%$ \\
\hline Human rights & Soc. & 19 & $43,2 \%$ \\
\hline Green investments & Ecol. & 18 & $40,9 \%$ \\
\hline Friendly corporate culture & Soc. & 18 & $40,9 \%$ \\
\hline $\mathrm{CO}_{2}$ & Ecol. & 16 & $36,4 \%$ \\
\hline Diversity management & Soc. & 16 & $36,4 \%$ \\
\hline Corporate governance & Econ. & 13 & $29,5 \%$ \\
\hline Protection of intellectual property & Econ. & 13 & $29,5 \%$ \\
\hline Low cost environment & Ecol. & 12 & $27,3 \%$ \\
\hline Fair competition & Econ. & 12 & $27,3 \%$ \\
\hline Marketing ethics & Econ. & 11 & $25,0 \%$ \\
\hline
\end{tabular}




\begin{tabular}{||l|r|r|r||}
\hline Fight against corruption & Econ. & 8 & $18,2 \%$ \\
\hline Work-life balance & Soc. & 7 & $15,9 \%$ \\
\hline
\end{tabular}

(Source: Own research processed in IBM SPSS 25.0)

The situation of foreign companies is different. The first half of the table includes dominantly dimensions of ecological and social sustainability (both $37.50 \%$ ). The third pillar was the pillar of economic sustainability. We can conclude that there were differences in preferences of the observed dimensions between Slovak and foreign entities. We can assume that this is caused by different approaches of company management, or their different preferences.

In order to determine, whether the differences are statistically significant, we conducted statistical testing, using Mann-Whitney $U$ test. Mann-Whitney $U$ test is a non-parametric test, which is based on a median (middle value of distribution). Thus, median significantly reduces the influence of extreme values.

\section{Table 9 Dimensions of CSR in Slovak and foreign companies (median)}

\begin{tabular}{||l|r|r|r||}
\hline & $\mathrm{N}$ & MEAN RANK & \multicolumn{1}{|c||}{ SUM OF RANKS } \\
\hline Slovak companies & 28 & 14,55 & 407,50 \\
\hline Foreign companies & 28 & 42,45 & 1188,50 \\
\hline Total & 56 & & \\
\hline
\end{tabular}

(Source: Own research processed in IBM SPSS 25.0)

The distribution of both independent samples (Slovak and foreign) prove that the differences in the final ranking of Slovak $(\mathrm{Mdn}=11.6)$ and foreign $(\mathrm{Mdn}=42.5), \mathrm{U}=1.50, \mathrm{z}=-6.43, \mathrm{r}=0.859, \mathrm{p}<.01$ are statistically significant. The analyzed relationship defines approximately $86 \%$ of the differences described. This is a very high dependency. We can therefore assume that the order of dimensions is significantly influenced by the country of origin of the company.

\section{Table 10 Dimensions of CSR in Slovak and foreign companies (Mann-Whitney test)}

\begin{tabular}{||l|r|}
\hline Mann-Whitney U & 1,500 \\
\hline Wilcoxon W & 407,500 \\
\hline Z & $-6,434$ \\
\hline Asymp. Sig. (2-tailed) &, 000 \\
\hline
\end{tabular}

(Source: Own research processed in IBM SPSS 25.0);

a. Grouping Variable: Country of origin

In both Slovak (80.0\%) and foreign (88.6\%) pharmaceutical companies, there was product safety and quality came at first place. The result can be perceived as a natural consequence as all companies have to meet high quality standards (GMP - Good Manufacturing Practice and European regulations), which are set by the European Agency (EMA) and transposed into national legislation (the Act no. 362/2001 call. on medical products and medical devices, and also manufacturing practice). Other dimensions placed differently in observed sample. 


\section{CONCLUSIONS}

The pharmaceutical industry is one of the most dynamic industries ever. This is not only because of the economic results achieved (Dukes, 2006), but also because of intensive research and innovations. The nature of the products produced, their focus and their use in the treatment of humans and animals makes of the pharmaceutical industry one of the most controlled and regulated sectors. A significant change is that companies are increasingly engaged in communication (Dumitrescu, 2016) towards stakeholder groups. The pharmaceutical sector has highly diversified interest groups. In this article we dealt with a specific area, namely the involvement of pharmaceutical companies in social responsibility. As early as 1973, Jacoby (1973) concluded that it is necessary to communicate social responsibility in order to eliminate the negative associations of corporations. Online communication, even in communicating CSR activities is an important change caused by the number of people with access to new technologies (Esrock \& Leichty, 1998). In terms of sustainability, the situation in both Slovak and foreign companies is relatively similar. In both cases, the economic pillar of sustainability dominates. However, looking at the dimensions of the individual pillars, the situation starts to be different. In Slovak enterprises, thre are mostly dimensions related to the pillar of ecological sustainability of business in the first half of the dimensions. The situation with foreign companies is a bit different. There are both dimensions of ecological and social sustainability placed in the first half. For most Slovak and most foreign pharmaceutical companies, product quality and safety comes first. Overall, Slovak manufacturers are aware of the necessity to communicate CSR through online communication. However, the results of the research cannot be completely generalized, as there are large differences between the pharmaceutical companies, which we alalysed. Large foreign corporations communicate best about CSR and use different means of communication. In case of Slovak and smaller companies we identified significant drawbacks in the way they communicate about their social responsibility. The main problem is that they do not use online communication sufficiently.

\section{Acknowledgements}

The paper is part of the research project VEGA 1/0502/17 "Consumer personality and its impact on emotional behaviour and decision making", which is currently underway at the Department of Marketing and Trade, Faculty of Economics and Management, Slovak University of Agriculture in Nitra.

\section{REFERENCES}

Arrenfeldt, K. (2015). CSR in the digital age. Retrieved from http: https://www.comprend.com/ blog/2015/csr-digital-age.

Bowen, H. (1953). Social Responsibilities of the Businessman. New York: Harper \& Row.

Bowen, S. (2004). Organizational Factors Encouraging Ethical Decision Making: An Exploration into the Case of an Exemplar. Journal of Business Ethics, 52(4), 311-324. https://doi.org/10.1007/s10551-004-1527-4

Caroll, A. B. (1979). A three dimensinal conceptual model of corporate social performance. The Academy of Management Review, 4(4), 497-505. https://doi.org/10.2307/257850.

Carroll, A. B. (1999). Corporate Social Responsibility. Evolution of a Definitional Construct. Business \& Society, 38(3), 268-295. https://doi.org/10.1177/000765039903800303

Chaffey, D., Ellis-Chadwick, F. (2016). Digital Marketing (6th Edition). Harlow: Pearson Education Limited.

Cheah, E. T., Chan, W. L. \& Chieng, C. L. (2007). The Corporate Social Responsibility of Pharmaceutical Product Recalls: An Empirical Examination of U.S. and U.K. Markets. Journal of Business Ethics, 76(4), 427-449. Retrieved from www.jstor.org/stable/25075530

Countess of Frederiksborg, A. \& Fort, T. L. (2014). The paradox of pharmaceutical CSR: The sincerity nexus. Business Horizons, 57(1), 151-160. https://doi.org/10.1016/j.bushor.2013.10.006 
Dahlsrud, A., 2008. How Corporate Social Responsibility is Defined: An Analysis of 37 definitions. Corporate Social Responsibility and Environmental Management, 15(1), 1-13. https://doi.org/10.1002/csr.132

De Pelsmacker, Geuens, M. \& Van Den Bergh, J. (2010). Marketing communications: A European perspective (4th ed.). Harlow: Pearson Education.

Dropper, H., Bennett, S. (2015). Corporate social responsibility in global health: an exploratory study of multinational pharmaceutical firms. In Globalization and Health, 11(15), 1-8. https://doi.org/10.1186/s12992-015-0100-5

Dukes, G. (2006). The Law and Ethics of the Pharmaceutical Industry. s.l.:Elsevier Science.

Dumitrescu, L. (2016). Globálne trendy ovplyvnuujuce farmacentický priemysel. Retrieved from https://www2.deloitte.com/content/dam/Deloitte/sk/Documents/Glob\%C3\%A1lne\%20trend y $\% 20$ ovplyv $\%$ C $5 \% 88$ uj $\%$ C $3 \%$ BAce $\% 20$ farmaceutick $\%$ C $3 \%$ BD $\% 20$ priemysel.pdf.

Džupina, M. (2012). Dimenzie spoločenskej zodpovednosti podnikov v slovenskej republike. Acta Oeconomica Universitatis Selye, 1(2), 59-70. Retrieved from: http://old.estudies.ujs.sk/hu/cimlap/doc_download/46-.html

Džupina, M. \& Džupinová, Z. (2016). Peculiarities of Corporate Social Responsibility in Veterinary Pharmacy. International Scientific Days 2016 : The Agri-Food Value Chain: Challenges for Natural Resources Management and Society. 256-263. http:/ / dx.doi.org/10.15414/isd2016.s4.03

Elkington, J. (1999). Cannibals With Forks. Oxford: Capstone Publishing Ltd.

Esrock, S. L. \& Leichty, G. B. (1998). Social responsibility and corporate web pages: Self-presentation or agenda-setting?. Public Relations Review, 24(3), 305-319. https://doi.org/10.1016/S03638111(99)80142-8

Esteban, D. (2008). Strengthening Corporate Social Responsibility in the Pharmaceutical Industry. Journal of Medical Marketing: Device, Diagnostic and Pharmaceutical Marketing, 8(1), 77-79. https://doi.org/10.1057/palgrave.jmm.5050126

European Commission. (2001, June 18). Green Paper (Promoting a European framework for Corporate Social Responsibility). Retrieved http://eur-lex.europa.eu/LexUriServ/LexUriServ.do? uri=COM:2001:0366:FIN:EN:PDF

Field, A. (2009). Discovering Statistics Using SPSS (3rd. Edition). London: SAGE Publishing.

Fort, T. L. (2014). The paradox of pharmaceutical CSR: The sincerity nexus. Business Horizons, 57(2), 151-160. https://doi.org/10.1016/j.bushor.2013.10.006

Frederick, W. C. (1960). The growing concern over business responsibility. California Management Review, 2(4), 54-61. https://doi.org/10.2307/41165405

Gomez, L. M. \& Chalmeta, R. (2011). Corporate responsibility in U.S. corporate website: Pilot study. Public Relations Review, 37(1), s. 93-95. https://doi.org/10.1016/j.pubrev.2010.12.005

Grougiou, V., Dedoulis, E., \& Leventis, S. (2016). Corporate Social Responsibility Reporting and Organizational Stigma: The Case of "Sin" Industries. Journal of Business Research, 69, 905-914. https://doi.org/10.1016/j.jbusres.2015.06.041

Hillenbrand, C., Money, K., \& Ghobadian, A. (2013). Unpacking the Mechanism by Which Corporate Responsibility Impacts Stakeholder Relationships. British Journal of Management, 24(1), 127-146. https://doi.org/10.1111/j.1467-8551.2011.00794.x

Hoeffler, S. \& Keller, K. L. (2002). Building brand equity through corporate societal marketing. Journal of Public Policy and Marketing, 21(1), 78-89. https://doi.org/10.1509/jppm.21.1.78.17600

Homburg, C., Kuester, S., Krohmer, H. (2009). Marketing management: A contemporary perspective. Maidenhead: McGraw-Hill.

Kašparová, K. \& Kunz, V. (2013). Moderni prǐstupy ke společenské odpovědnosti firem a CSR reportování. Praha: Grada Publishing.

Kesavan, R. , Bernacchi, M. D. \& Mascarenhas, O. A. (2013). Word of Mouse: CSR Communication and Social Media. International Management Review, 9(1), 58-66.

Esrock, S. L. \& Leichty, G. B. (1998). Social responsibility and corporate web pages: Self-presentation or agenda-setting?. Public Relations Review, 24(3), 305-319. https://doi.org/10.1016/S03638111(99)80142-8 
Jacoby, N. H. (1973). Corporate Power and Social Responsibility. New York, NY: Macmillan.s

Leisinger, K. M. (2005). The Corporate Social Responsibility of The Pharmaceutical Industry: Idealism Without Illusion and Realism Without Resignation. Business Ethics Quarterly, 15(4), 577-594. Retrieved from www.jstor.org/stable/3857979

Manheim, J. B., \& Pratt, C. B. (1986). Communicating corporate social responsibility. Public Relations Review, 12(2), 9-18. https://doi.org/10.1016/j.pubrev.2017.06.007

Minoja, M., \& Romano, G. (2010). Managing Turnaround with Responsible Entrepreneurship: The Kedrion Case. Role of The Ceo: Managing Beyond Matrix. Retreived from: https: / / ssrn.com/abstract $=1725194$

Nielsen, A. E., \& Thomsen, C. (2007). Reporting CSR - what and how to say it?. Corporate Communications: An International Journal, 25-40. https://doi.org/10.1108/13563280710723732

Nussbaum, A. K. (2008). Ethical corporate social responsibility (CSR) and the pharmaceutical industry: A happy couple?. Journal of Medical Marketing, 9(1), 67-76. https://doi.org/10.1057/jmm.2008.33

Porter, M. E. \& Kramer, M. R. (2002). The Competitive Advantage of Corporate Philanthropy. In Harvard Business Review, 80, 56-68. Retreived from: https://hbr.org/2002/12/the-competitiveadvantage-of-corporate-philanthropy

Reisel, W. D. \& Sama, L. M. (2003). The Distribution of Life-Saving Pharmaceuticals: Viewing the Conflict Between Social Efficiency and Economic Efficiency Through a Social Contract Lens. Business and Society Review, 108(3), 365-387. https://doi.org/10.1111/1467-8594.00169

Ryan, M. (2003). Public relations and the web: organizational problems, gender and institution type. Public Relations Review, 29(3), 335-349. https://doi.org/10.1016/S0363-8111(03)00040-7

Seknička, P. \& Putnová, A. (2016). Etika v podnikání a hodnoty trbu. Praha: Grada Publishing.

Sethi, S. P. (1975). Dimensions of Corporate Social Performance: An Analytic Framework. California Management Review, 17, 58-64. https://doi.org/10.2307/41162149

Smith, C. N. (2003). Corporate Social Responsibility: Whether or How?. California Management Review, 45(4), 52-76. https://doi.org/10.2307/41166188

Stone, M., Grantham, S., \& Vieira, E. T. (2009). Communicating CSR via pharmaceutical companyweb sites. Evaluating message frameworks for external and internal stakeholders. Corporate $\begin{array}{llllll}\text { Communications: An International Journal, } 14 & \text { (2), }\end{array}$ https://doi.org/10.1108/13563280910953834

Story, D. \& Price, T. J. (2006). Corporate social responsibility and risk management. The Journal of Corporate Citizenship, (22), 39-51. Retrieved from www.jstor.org/stable/jcorpciti.22.39

Tapscott, D. \& Tiscoll, D. (2003). The Naked Corporation: How the Age of Transparency Will Revolutionize Business. New York, NY: Free Press.

Uzunoglu, E. \& Kip, S. M. (2014). Brand communication through digital influences: Leveraging blogger engagement. International Journal of Information Management, 34(1), 592-602. https://doi.org/10.1016/j.ijinfomgt.2014.04.007

Vegne, J. P. (2012). Stigmatized Categories and Public Disapproval of Organizations: A Mixed-methods Study of the Global Arms Industry, 1996-2007. Academy of Management Journal, 55(5), 1027-1052. http://dx.doi.org/10.5465/amj.2010.0599

Vitezić, N. (2010). A Measurement System Of Corporate Social Responsibility In The Pharmaceutical Industry of The Region. International Journal of Management \& Information Systems, 10(5), 57-68. https://doi.org/10.19030/ijmis.v14i5.13

Vogel, D. (2005). The Market for Virtue: The Potential And Limits of Corporate Social Responsibility. Washington: The Brookings Institution Press

Weber, R. P. (1990). Basic Content Analysis (Quantitative Applications in the Social Sciences). London, UK: Sage Publications

Weyzig, F. (2004). Sector profile of the pharmaceutical industry. Retreived from: https://www.somo.nl/html/paginas/pdf/Sector_profile pharmecautical_industry_2004_EN.pdf.

World Health Organization. (2016). Retrieved from: http://www.who.int/trade/glossary/story073/en/ 